\title{
NOISE REDUCTION IN FUEL INJECTION PUMPS OF TRACTOR ENGINES USING 'IS AND IS-NOT APPROACH'
}

\author{
C S Chethan Kumar ${ }^{1}$, P R Dheeraj ${ }^{2}$, Augustus Wilander D'Costa ${ }^{3}$

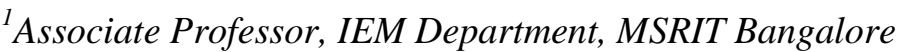 \\ ${ }^{2}$ Assistant Professor, IEM Department, MSRIT Bangalore \\ ${ }^{3}$ M.Tech Student, IEM Department, MSRIT Bangalore
}

\begin{abstract}
An industry makes fuel injection pumps for tractor engines. Recently it was observed that the fuel injection pumps were making too much noise in the engines. The problem-solving techniques of industrial engineering were used to solve this problem. One such simple but powerful problem-solving technique is the 'is and is-not' approach. This technique was used to identify the root cause of the increased noise of the fuel injection pumps. Once the cause was identified, the problem was rectified. Thus the industry was able to reduce the noise of the fuel injection pumps.
\end{abstract}

Keywords: Fuel injection pumps, Control rack, Wire over dimension readings, Rack \& Pinion mechanism, Rack milling process, is and is-not.

\section{INTRODUCTION}

The fuel-injection system is responsible for supplying the diesel engine with fuel. To do so, the injection pump generates the pressure required for fuel injection. The fuel under pressure is forced through the high-pressure fuelinjection tubing to the injection nozzle which then injects it into the combustion chamber. The fuel-injection system includes the following components and assemblies: The fuel tank, the fuel filter, the fuel-supply pump, the injection nozzles, the high-pressure injection tubing, the governor, and the timing device (if required). The combustion processes in the diesel engine depend to a large degree upon the quantity of fuel which is injected and upon the method of introducing this fuel to the combustion chamber.

The most important criteria in this respect are the fuelinjection timing and the duration of injection, the fuel's distribution in the combustion chamber, the moment in time when combustion starts, the amount of fuel metered to the engine per degree crankshaft, and the total injected fuel quantity in accordance with the engine loading. The optimum interplay of all these parameters is decisive for the faultless functioning of the diesel engine and of the fuelinjection system.

\section{REJECTION STATUS OF THE PUMPS}

\subsection{Internal Rejection of Pumps at the Plant}

A graph of rejections for the pumps types 939, 941 and A08 as of months July 2015 to December 2016 is in Figure 1. The $\mathrm{X}$-axis of the graph shows months in which the rejections of the pumps are seen at the plant of the company after the assembly of parts and the Y-axis shows the percentage of the rate of rejections for all the three pumps respectively. The figures for the total number of pumps assembled per month with the corresponding rejection rates for all the three pump types respectively are displayed in Table 1 .

\subsection{Rejections of the Pump during Engine Testing at the Customer End}

A graph of rejections for the pumps types A08, 939 and 941 as of months August 2015 to March 2016 is as shown in Figure 2. The $\mathrm{X}$-axis of the graph shows months in which the rejections of the pumps are seen at the plant of the company after the assembly of parts and the Y-axis shows the percentage of the rate of rejections for all the three pump types respectively. 


\section{Int. Rej}

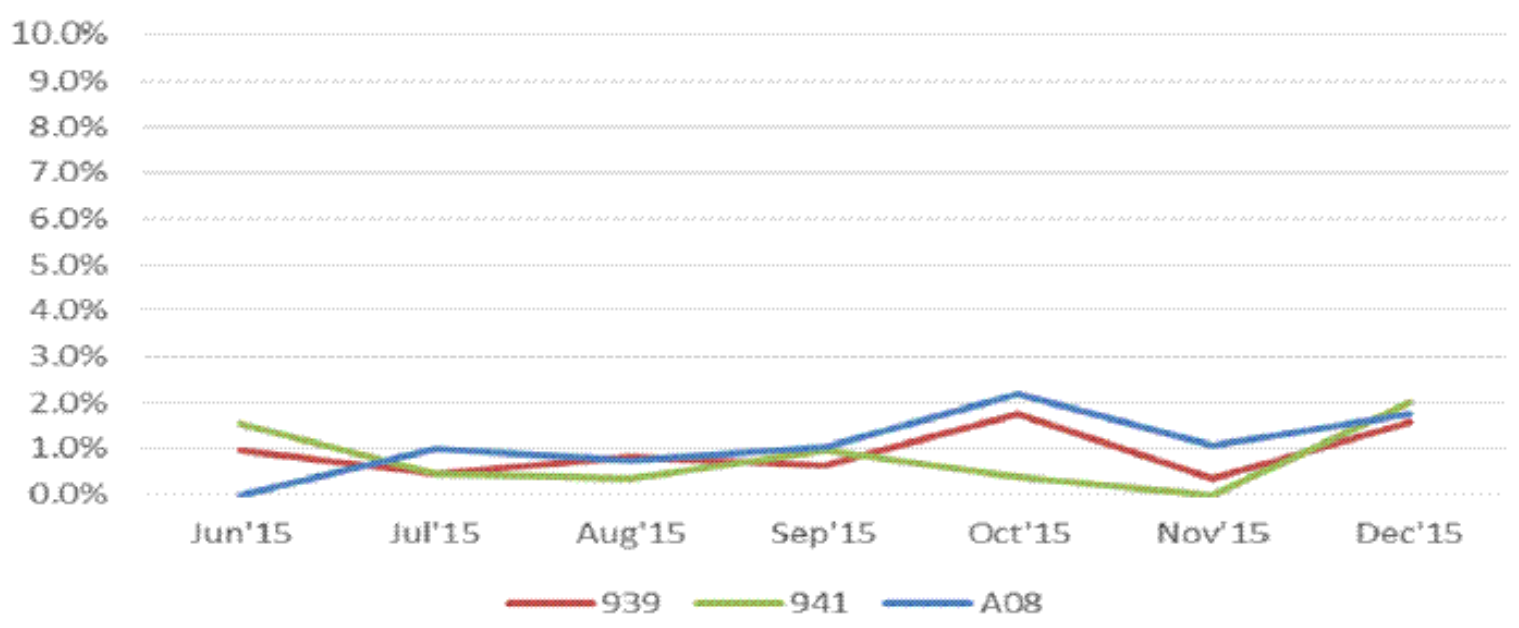

Fig 1: Rejection rate of pumps at the plant

Table 1: Internal rejection of pumps at the plant

\begin{tabular}{|l|l|l|l|l|l|l|l|l|l|l|}
\hline \multicolumn{2}{|l|}{ INTERNAL REJECTION OF PUMPS AT THE PLANT } \\
\hline \multirow{2}{*}{ MONTH } & A08 TYPE PUMP & \multicolumn{1}{l|}{ 939 TYPE PUMP } & 941 TYPE PUMP \\
\cline { 2 - 11 } & ASSY & REJ & $\%$ REJ & ASSY & REJ & $\%$ REJ & ASSY & REJ & $\%$ REJ \\
\hline JUN & 24 & 0 & $0 \%$ & 515 & 5 & $1 \%$ & 592 & 9 & $1.5 \%$ \\
\hline JUL & 1098 & 11 & $1 \%$ & 640 & 3 & $0.5 \%$ & 671 & 3 & $0.4 \%$ \\
\hline AUG & 1243 & 9 & $0.7 \%$ & 619 & 5 & $0.8 \%$ & 572 & 2 & $0.3 \%$ \\
\hline SEP & 964 & 10 & $1 \%$ & 640 & 4 & $0.6 \%$ & 624 & 6 & $1 \%$ \\
\hline OCT & 962 & 21 & $2.2 \%$ & 968 & 17 & $1.8 \%$ & 803 & 3 & $0.4 \%$ \\
\hline NOV & 649 & 7 & $1.1 \%$ & 301 & 1 & $0.3 \%$ & 5 & 0 & $0 \%$ \\
\hline DEC & 399 & 7 & $1.8 \%$ & 63 & 1 & $1.6 \%$ & 150 & 3 & $2 \%$ \\
\hline
\end{tabular}

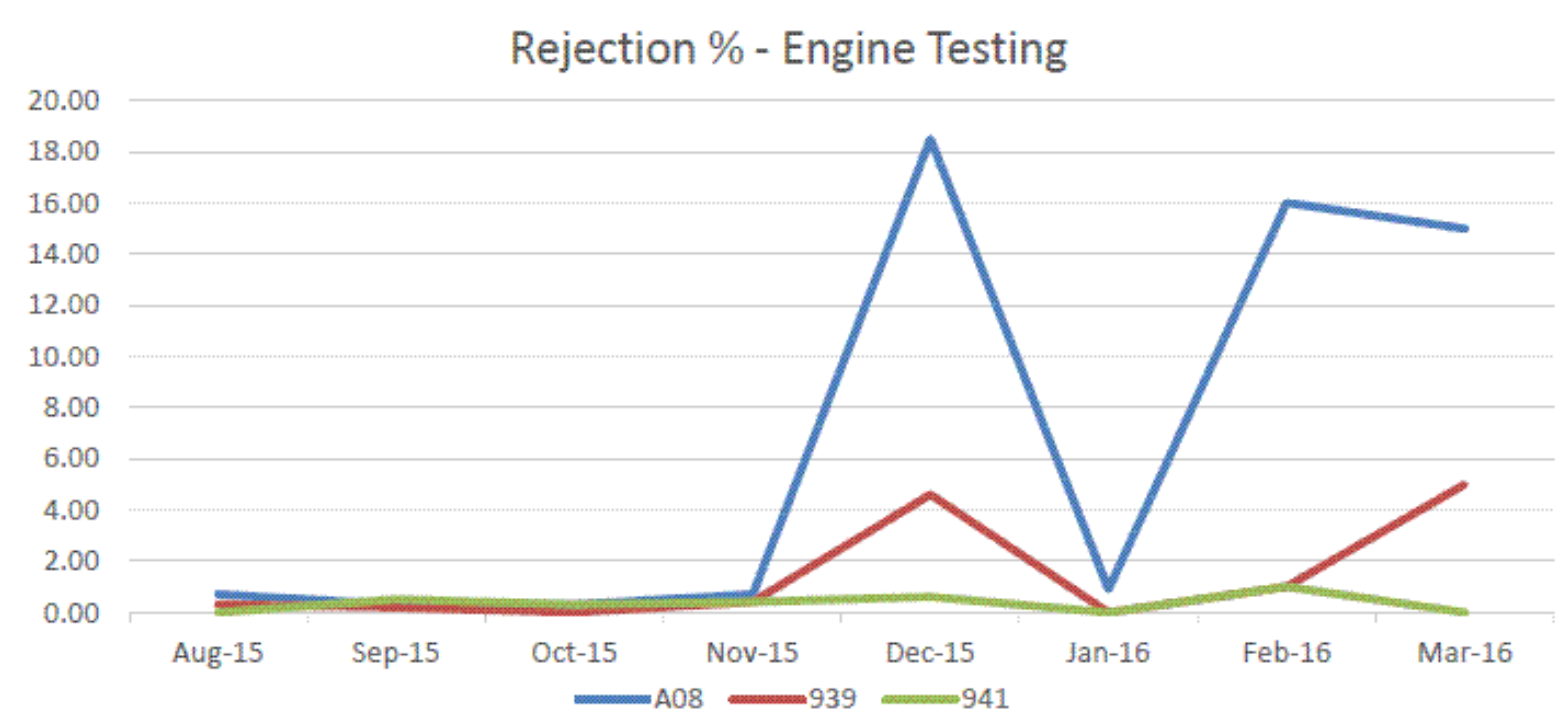

Fig 2: Rejection of pumps during engine testing at the customer end

The figures for the total number of pumps assembled per month and their corresponding rejection rates for all the pump types respectively are displayed Table 2 . From the graph it is very well evident that the rejection rate of the pumps A08 and 939 start to arise somewhere in the mid of November and hitting the peak of rejections of about $18.5 \%$ and $4.6 \%$ respectively for both types in the month of December and then subsiding to a reduction in the rejection rates subsequently in the month of January 2016. Similar trend of occurrence was also seen arising back again in the mid of January, with the peak of rejections reaching $16 \%$ in February and dropping down to a $\%$ of 15 in the month of 
march for the A08 pumps as shown from the graph. Hence this particular pump type results with the highest number of rejections overall compared to the 939 type. By comparisons made with the target and actual state standard graphs and analysing on how the

A graph of rejections for the pump type A08 as of November 2015 is shown in Figure 3. The X-axis of the graph displays the days of the month in which, a higher rate of rejections for the pump type that was recorded on a daily basis after the assembly operation. The Y-axis shows the total number of productions and the corresponding rate of rejections of the pump type per day.
The figures for the total number of pumps produced per day and their rejection rates are all displayed in the table below. The month of November has been taken as a basis to project on the highest number of rejections recorded on a month which showed to have risen drastically over a period of time. The total number of productions for the pump type has varied from day to day as per requirement. In particular, on the 11th of this particular month a rejection rate as high as $93 \%$ i.e. 40 out 43 numbers had been recorded.

Table 2: Rejection of pumps during engine testing at the customer end

\begin{tabular}{|l|l|l|l|l|l|l|l|l|l|}
\hline REJECTION OF PUMPS DURING ENGINE TESTING AT THE CUSTOMER END \\
\hline \multirow{2}{*}{ MONTH } & A08 TYPE PUMP & 939 TYPE PUMP & \multicolumn{3}{l|}{941 TYPE PUMP } \\
\cline { 2 - 10 } & ASSY & REJ & $\%$ REJ & ASSY & REJ & $\%$ REJ & ASSY & REJ & $\%$ REJ \\
\hline JUN & 802 & 4 & $0.5 \%$ & 789 & 3 & $0.4 \%$ & 405 & 2 & $0.5 \%$ \\
\hline JUL & 617 & 3 & $0.5 \%$ & 697 & 3 & $0.4 \%$ & 689 & 4 & $0.6 \%$ \\
\hline AUG & 1051 & 7 & $0.7 \%$ & 630 & 2 & $0.3 \%$ & 512 & 0 & $0 \%$ \\
\hline SEP & 1037 & 3 & $0.3 \%$ & 848 & 2 & $0.2 \%$ & 652 & 3 & $0.5 \%$ \\
\hline OCT & 934 & 3 & $0.3 \%$ & 537 & 0 & $0 \%$ & 306 & 1 & $0.3 \%$ \\
\hline NOV & 601 & 4 & $0.7 \%$ & 274 & 1 & $0.4 \%$ & 278 & 1 & $0.4 \%$ \\
\hline DEC & 417 & 77 & $18.5 \%$ & 388 & 18 & $4.6 \%$ & 356 & 2 & $0.6 \%$ \\
\hline JAN & 107 & 1 & $0.9 \%$ & 92 & 0 & $0 \%$ & 0 & 0 & $0 \%$ \\
\hline FEB & 486 & 78 & $16 \%$ & 218 & 2 & $1 \%$ & 177 & 2 & $1 \%$ \\
\hline MAR & 565 & 85 & $15 \%$ & 406 & 20 & $5 \%$ & 0 & 0 & $0 \%$ \\
\hline
\end{tabular}

\section{Day wise rejections - A08}

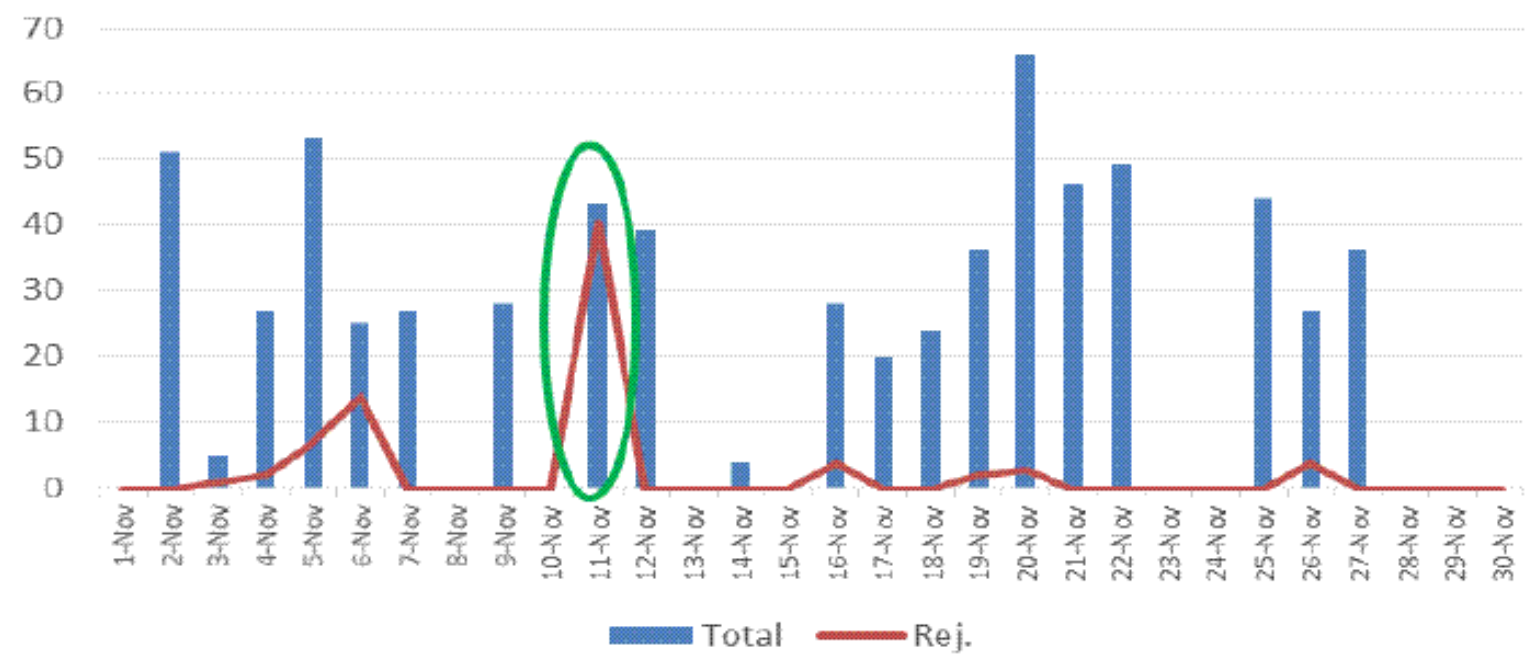

Fig 3: Daywise rejection of pumps for a particular month

Table 3: Daywise rejection of pumps for a particular month A08 TYPE PUMP - DAYWISE REJECTIONS

\begin{tabular}{|l|l|l|l|}
\hline DATE & TOTAL PRODN & NO OF REJECTIONS & $\%$ OF REJECTIONS \\
\hline 01-Nov-15 & 0 & 0 & $0 \%$ \\
02-Nov-15 & 51 & 0 & $0 \%$ \\
03-Nov-15 & 5 & 1 & $20 \%$ \\
04-Nov-15 & 27 & 2 & $7.4 \%$ \\
05-Nov-15 & 7 & $13.2 \%$ \\
06-Nov-15 & 53 & 14 & $56 \%$ \\
\hline
\end{tabular}




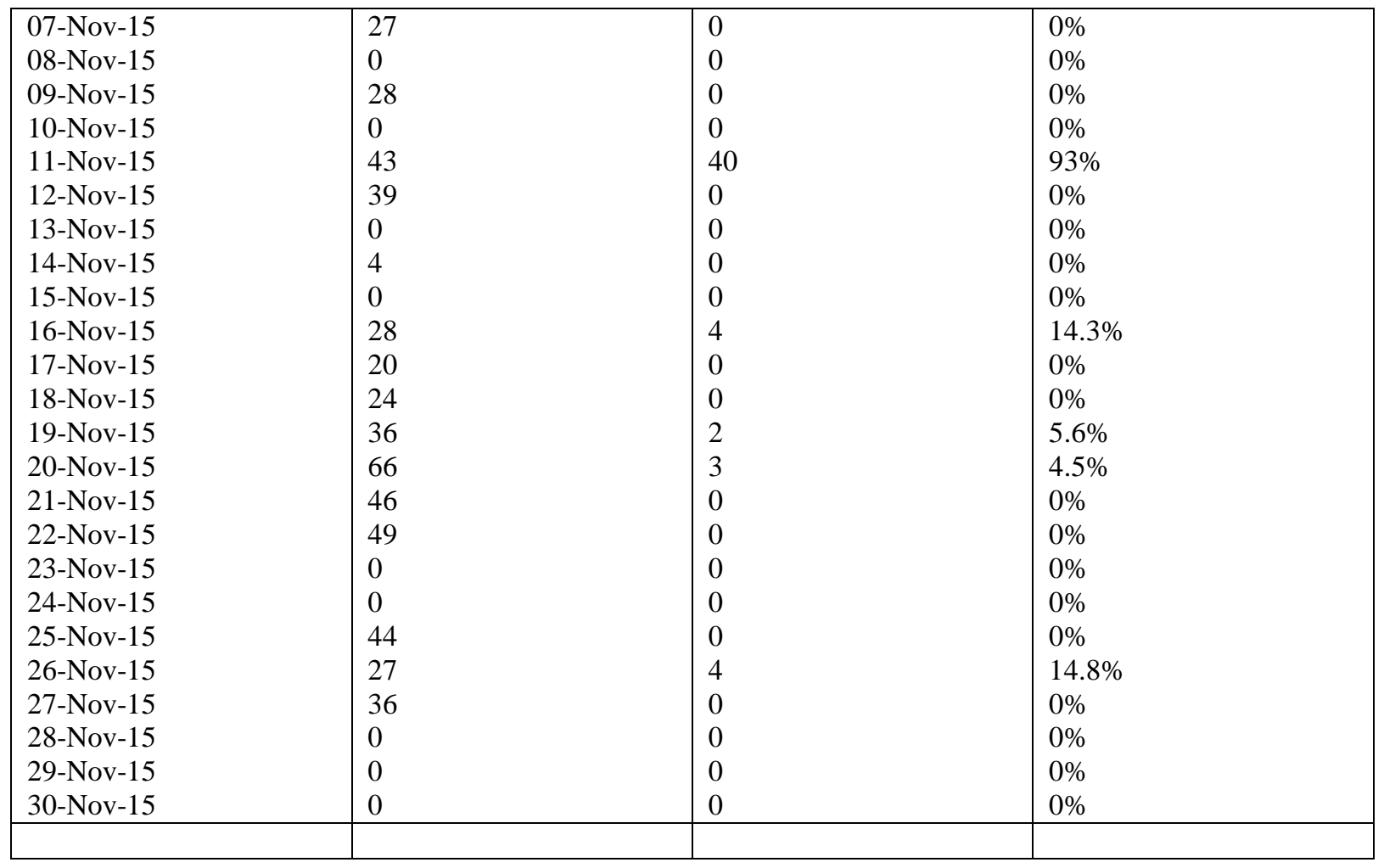

\section{Facts Collection from the Graphs and Tables - IS}

\section{\& IS NOT Approach}

- The initial facts collection is based on contrast "IS-IS NOT" approach in which the actual state of the factors in the form of what could be the issue and what could not are both compared and an inference is drawn from it.

- Therefore the contrast shows that the problem is with the A08 pump type, with its predecessor being the pump type 939 and the problem is not in this case is for pump type 941.

- Both the pumps face rejections but the extent to which the rejections are observed between them varies.

- It was also seen that the issue had suddenly started when A08 pump was introduced for $40.8 \mathrm{Hp}$ application.

- It could also be seen that the pump type A08 appears to have the highest rate of rejections compared to the 939 pump type.

- This helps in defining the fundamental problem.

\section{'IS \& IS NOT' APPROACH}

The entire Summary is based in the form an approach known as IS and IS NOT. The approach has been generally used by the quality department of the automotive industry. According to this approach the facts are collected in a structured way by using the key questions on "what, where, when, who and how many" has shown to be of great help. The answers to the basic questions on

- What exactly is the problem?

- Where exactly is the problem observed?
- When exactly is the problem observed?

- Who observed the problem for the first time?

- How often exactly does the problem occur?

- How much/many is/are affected? are all documented in a tabular form under the so called "Is"column.

Under the heading of "The problem is not" a search for a comparable/similar facts is made.

- What (situations, processes, sequences, functions, defects, deviations, errors)

- Where (countries, regions, plants, departments, processes, lines, workplaces, work steps, positions on the object)

- When (months, weeks, days, times/periods, shifts, chronological rhythms)

- Scale (quantities, rhythms, intervals) that are not, but could be, affected by the problem. Important here is the stress on the second clause "but could be", i.e. only relevant areas are included in the demarcation, otherwise one would become lost in the variety of possibilities. There must be at least one difference or special feature, otherwise the IS-NOT areas would also be affected by the problem. The template of the approach is shown below. 
Table 4: 'Is and Is-not' approach facts collection

\begin{tabular}{|l|l|l|l|}
\hline & IS*(Predecessor) & IS & NOT IS \\
\hline Pump & 939 & 941 & A08 \\
\hline Engine & E3.215 & E3.215 & E3.234 \\
\hline Engine Rating & $37 \mathrm{Hp} @ 2200 \mathrm{rpm}$ & $34 \mathrm{Hp} @ 2200 \mathrm{rpm}$ & $40.8 \mathrm{Hp} @ 2200 \mathrm{rpm}$ \\
\hline Volume & $2150 \mathrm{cc}$ & $2150 \mathrm{cc}$ & $2340 \mathrm{cc}$ \\
\hline Application & Tractor PT 439 & Tractor PT 434 & Tractor PT 439 DS plus \\
\hline
\end{tabular}

Table 5: 'Is and Is-not' approach

\begin{tabular}{|c|c|c|c|}
\hline WHO & IS & $\begin{array}{l}\text { IS NOT } \\
\text { (But could be?) }\end{array}$ & CONTRAST \\
\hline Is the Problem with & $\begin{array}{l}\text { Customer } \\
\text { manufacturer) }\end{array}$ & Other Customers & $\begin{array}{l}\text { No claims from any other } \\
\text { customers so far }\end{array}$ \\
\hline $\begin{array}{l}\text { Observed the failure at the } \\
\text { engine level }\end{array}$ & Customer & Company & $\begin{array}{l}\text { Customer rejection report } \\
\text { during engine testing for } \\
\text { pump types }\end{array}$ \\
\hline $\begin{array}{l}\text { Observed the failure at the } \\
\text { (pump level) }\end{array}$ & Company & Customer & $\begin{array}{l}\text { Performing shainin trials on } \\
\text { good \& bad pumps by } \\
\text { swapping them }\end{array}$ \\
\hline $\begin{array}{l}\text { Observed the failure at the } \\
\text { (component level) }\end{array}$ & Company & Customer & $\begin{array}{l}\text { Performing shainin trials by } \\
\text { swapping components } \\
\text { between good \& bad pumps }\end{array}$ \\
\hline HOW MANY & IS & $\begin{array}{l}\text { IS NOT } \\
\text { (But could be?) }\end{array}$ & CONTRAST \\
\hline $\begin{array}{l}\text { Pumps showed failure in total } \\
\text { during the engine testing in } \\
\text { November? }\end{array}$ & $77 / 678$ & $601 / 678$ & $\begin{array}{l}\text { Particular month where } \\
\text { highest rejection rates were } \\
\text { noticed drastically }\end{array}$ \\
\hline $\begin{array}{l}\text { A08 pumps showed failure } \\
\text { from June } 2015 \text { to March } \\
2016 \text { during engine testing? }\end{array}$ & $265 / 6617$ & $6352 / 6617$ & $\begin{array}{l}\text { A08 pumps showed failure } \\
\text { from June } 2015 \text { to March } \\
2016 \text { during engine testing }\end{array}$ \\
\hline $\begin{array}{l}939 \text { pumps showed failure } \\
\text { from June } 2015 \text { to March } \\
2016 \text { during engine testing? }\end{array}$ & $51 / 4879$ & $4828 / 4879$ & $\begin{array}{l}939 \text { pumps showed failure } \\
\text { from June } 2015 \text { to March } \\
2016 \text { during engine testing }\end{array}$ \\
\hline $\begin{array}{l}941 \text { pumps showed failure } \\
\text { from June } 2015 \text { to March } \\
2016 \text { during engine testing? }\end{array}$ & $15 / 3375$ & $3360 / 3375$ & $\begin{array}{l}941 \text { pumps showed failure } \\
\text { from June } 2015 \text { to March } \\
2016 \text { during engine testing }\end{array}$ \\
\hline WHERE & IS & $\begin{array}{l}\text { IS NOT } \\
\text { (But could be?) }\end{array}$ & CONTRAST \\
\hline Is the problem observed? & F002 Z11 A08, 939 Pump & 941 Pump & $\begin{array}{l}\text { The rejection rate of each } \\
\text { pump is observed. }\end{array}$ \\
\hline Is the object with defect? & $\begin{array}{l}\text { Control Rack meshing with } \\
\text { the pinion }\end{array}$ & $\begin{array}{l}\text { Gear segments meshing \& } \\
\text { other components of the } \\
\text { pump }\end{array}$ & $\begin{array}{l}\text { Meshing of CR \& gear } \\
\text { segments show fluctuations } \\
\text { in noise \& cause vibrations }\end{array}$ \\
\hline $\begin{array}{l}\text { Is the defect at the component } \\
\text { (From Analysis)? }\end{array}$ & $\begin{array}{l}\text { Wire Over Dimension }(9.25 \text { - } \\
0.08 \mathrm{~mm})\end{array}$ & $\begin{array}{l}\text { Run out, dimension, } \\
\text { parallelism }\end{array}$ & \begin{tabular}{lrr} 
Pump & \multicolumn{2}{c}{ Components } \\
measurements & show a \\
contrast in WOD & & \\
\end{tabular} \\
\hline $\begin{array}{l}\text { Specifically is the problem in } \\
\text { the component? }\end{array}$ & Lower Specification of WOD & Higher Specification of WOD & $\begin{array}{l}\text { All good pump component } \\
\text { measurements show WOD on } \\
\text { the higher end side compared } \\
\text { to bad pump comp } \\
\text { measurements }\end{array}$ \\
\hline $\begin{array}{l}\text { In the Control Rod WOD } \\
\text { Normal process is observed } \\
\text { failure? }\end{array}$ & Milling & $\begin{array}{l}\text { Blackening, Buffing, Bend } \\
\text { removal }\end{array}$ & $\begin{array}{l}\text { CR milling shows large } \\
\text { process variation }\end{array}$ \\
\hline $\begin{array}{l}\text { Is the component observed } \\
\text { with failure? (From analysis) }\end{array}$ & HMT machine 7616 & Kirloskar machine 6025 & $\begin{array}{l}\text { Machine } 7616 \text { reconditioned } \\
\text { due to the various issues } \\
\text { identified }\end{array}$ \\
\hline $\begin{array}{l}\text { In the machine is the object } \\
\text { observed with failure? (From }\end{array}$ & Fixture, spindle, machine bed & Other Process Parameters & $\begin{array}{l}\text { Fixture deformation or taper } \\
\text { affects the control rack }\end{array}$ \\
\hline
\end{tabular}




\begin{tabular}{|c|c|c|c|}
\hline analysis) & & & dimensions \\
\hline $\begin{array}{l}\text { In the machine is the problem } \\
\text { again observed? (From } \\
\text { analysis) }\end{array}$ & Spindle RPM \& Run out & Other Process Parameters & $\begin{array}{l}\text { Cutting speed affects the } \\
\text { control rack dimensions, as } \\
\text { cutting speed is proportional } \\
\text { to cutting force }\end{array}$ \\
\hline $\begin{array}{l}\text { In the machine is the problem } \\
\text { again observed? (From } \\
\text { analysis) }\end{array}$ & Table movement & Other Process Parameters & $\begin{array}{l}\text { Machine table movement is } \\
\text { jerky against the ideal } \\
\text { condition }\end{array}$ \\
\hline WHAT & IS & $\begin{array}{l}\text { IS NOT } \\
\text { (But could be?) }\end{array}$ & CONTRAST \\
\hline Has been the Problem with & $\begin{array}{l}\text { In-House } \quad \text { Manufacturing } \\
\text { Process }\end{array}$ & Supplier pre-parts & $\begin{array}{l}\text { Measurements of the pre- } \\
\text { parts before milling, after } \\
\text { milling, after blackening \& } \\
\text { after bend removal show that } \\
\text { supplier pre-parts are not the } \\
\text { issue }\end{array}$ \\
\hline $\begin{array}{l}\text { Is the issue leading to the } \\
\text { failure? }\end{array}$ & Process & Measurement & $\begin{array}{l}\text { Isoplot shows process is the } \\
\text { issue, not the measurement }\end{array}$ \\
\hline WHEN & IS & $\begin{array}{l}\text { IS NOT } \\
\text { (But could be?) }\end{array}$ & CONTRAST \\
\hline $\begin{array}{l}\text { Object with defect observed } \\
\text { first, where geographically } \\
\text { was the observed or claimed } \\
\text { object with defect? }\end{array}$ & Customer End & Company & $\begin{array}{l}\text { Pumps were identified with } \\
\text { high fluctuations in noise at } \\
\text { the customer end initially, as } \\
\text { and when there were engine } \\
\text { tests run on the vehicles } \\
\text { resulting with the engine not } \\
\text { running smooth }\end{array}$ \\
\hline $\begin{array}{l}\text { Was the object started } \\
\text { showing more no of defects? } \\
\text { (At pump level) }\end{array}$ & November 2015 & August 2015 - October 2015 & $\begin{array}{l}\text { A08 rejection rate gradually } \\
\text { peaks and subsides over a } \\
\text { period of time along with the } \\
\text { type } 939 \text { with a similar } \\
\text { pattern observed, but to a } \\
\text { lower extent of rejection rate }\end{array}$ \\
\hline $\begin{array}{l}\text { Again trend, repetition, } \\
\text { rhythm of } \\
\text { observed? }\end{array}$ & January 2016 & March 2016 & $\begin{array}{l}\text { Similarly there is a trend or a } \\
\text { repetition in the rejection rate } \\
\text { peaking \& subsiding over a } \\
\text { period of time }\end{array}$ \\
\hline
\end{tabular}

\section{CONCLUSION}

Multi-vari analysis helps in increasing quality by reducing process variability and aligning customer's expectations, providing financial returns to the management by avoiding the defect and rejection rates. The application of shainin trials have also been effective in finding out the project area at the initial level. These techniques used by shainin are increasing to be widely used as a method for problem solving by the quality department of various manufacturing firms worldwide. In this context, this project has been carried out for finding the root cause. The actual parameters were identified and the improvement in the required areas were proposed and made.

\section{REFERENCES}

[1]. Diesel In-Line Fuel-Injection Pumps, year 2003: Robert Bosch Gmbh (Gesellschaft mit beschrankter Haftung).

[2]. Sadhu Singh, "Theory of Machines", Second Edition, Chapter 8 \& 11, year 2008 Copyright 2006 Dorling Kindersley (India) pvt. Ltd.
[3]. Problems in Bosch Diesel Fuel Injection Pump and Its Effects - A Review, Indian Journal of Applied Science, Vol. 3, Dec 2013.

[4]. Bosch problem solving _booklet 16 - Clinical Quality Measures \& Boeing Quality Management System.

[5]. Bosch Exercise book DOE Tool \# 5 - Multi vari Analysis.

[6]. Shainin Strategies - Pocket Guide. Unterschleißheim: Shainin, 2007. 